\title{
Peningkatan Ekonomi Masyarakat: Dampak Pemanfaatan Ampas Susu Kedelai Menjadi Nugget
}

\author{
Laila Puspita*1, Komarudin² \\ 1Program Studi Pendidikan Bologi, Fakultas Tarbiyah dan Keguruan, Universitas Islam Negeri Raden Intan \\ Lampung \\ ${ }^{2}$ Program Studi Pendidikan Matematika, Fakultas Tarbiyah dan Keguruan, Universitas Islam Negeri Raden \\ Intan Lampung \\ *e-mail: lailapuspita@radenintan.ac.id ${ }^{1}$, komarudin@radenintan.ac.id ${ }^{2}$
}

\begin{abstract}
Soy milk is one of the processed products of soybean which has multi function for body health so it is safe to consume for daily drink. In Desa Banjarsari of Talang Padang District, there is the soy milk industry, when producing soy milk leaving soybean pulp. The purpose of this activity is to increase the community's economy through the utilization of soy milk residue into nuggets. The methods undertaken are by way of approach, practice, counseling, technical guidance, and mentoring. From this activity, it is known that the participants enthusiastically from PKK mothers to acquire the skills and ability to use soy milk pulp as an processed product in the form of nutritional-rich nuggets. The stimulus to increase the community's economy was well-responded by the participants, thereby providing hope for the improvement of quality of animal food consumption and opening opportunities to PKK mothers to carry out continuing continuity and sustainability activities so that PKK mothers can be built.
\end{abstract}

Keywords: Soybean pulp; Nugget Increased Econmi.

\begin{abstract}
Abstrak
Susu kedelai merupakan salah satu produk olahan dari kacang kedelai yang memiliki multi fungsi untuk kesehatan tubuh sehingga aman dikonsumsi untuk minuman sehari-hari. Di Desa Banjarsari Kecamatan Talang Padang Kabupaten Tanggamus terdapat industri susu kedelai, Saat memproduksi susu kedelai menyisakan ampas sus kedelai. Tujuan dari kegiatan ini adalah untuk meningkatkan ekonomi masyarakat melalui pemanfaatan ampas susu kedelai menjadi nugget. Metode yang dilakukan adalah dengan cara pendekatan, praktek, penyuluhan, bimbingan teknis, dan pendampingan. Dari kegiatan ini dapat diketahui bahwa antusias peserta dari ibu-ibu PKK untuk memperoleh keterampilan dan kemampuan tentang pemanfaatan ampas susu kedelai sebagai produk olahan berupa nugget yang kaya akan gizi. Rangsangan untuk meningkatkan ekonomi masyarakat direspon dengan baik oleh peserta, sehingga memberikan harapan bagi upaya perbaikan kualitas konsumsi pangan hewani dan membuka peluang kepada ibu-ibu PKK untuk melakukan kegiatan lanjutan yang bersifat kontinuitas dan berkesinambungan sehingga ibu-ibu PKK dapat terbina.
\end{abstract}

Kata kunci: Ampas Kedelai; Nugget; Peningkatan Ekonmi.

\section{PENDAHULUAN}

Kedelai merupakan komoditas pangan penghasil protein nabati yang sangat penting karena gizinya, aman dikonsumsi dan harganya yang relatif murah dibandingkan dengan sumber protein hewani (Septifani 2018; Pamuji 2018; Panataria 2015). Di Indonesia kedelai umumnya dikonsumsi dalam bentuk pangan olahan seperti tahu, tempe, susu kedelai dan berbagai bentuk makanan ringan (Haliza, Purwani, and Thahir 2016; Ariani 2015).

Salah satu manfaat dari kandungan olahan kacang kedelai adalah adanya kefir. Kefir merupakan minuman probiotik hasil fermentasi susu oleh bakteri asam laktat dah khamir yang memiliki manfaat yang baik bagi kesehatan, terutama teradap saluran pencernaan (Zaini 2016). Kefir mempunyai manfaat bagi kesehatan antaralain dapat memperbaiki proses pencernaan dan mempunyai kandungan protein yang tinggi (Susilawati 2018). Mutu protein pada kacang kedelai tidak kalah dengan susu sapi (Rohmani, Yugatama, and Prihapsara 2018; Ernawati 2013). Hal tersebut menjadikan kandungan kacang kedelai menjadi penting bagi kesehatan tubuh manusia. 
Permintaan susu kedelai meningkat seiring dengan meningkatnya kebutuhan akan gizi untuk beberapa orang yang menderita penyakit tertentu dan alergi terhadap protein hewani. Selain itu beberapa balita alergi terhadap laktosa sehingga dianjurkan mengkonsumsi produk pangan lain yang mempunyai kandungan gizi hampir sama dengan susu hewani (Wiyarsi 2005). Kondisi ini membuat semakin banyak bermunculan usaha pengolahan kacang kedelai, termasuk di desa Banjarsari.

Desa Banjarsari merupakan salah satu desa di Kecamatan Talang Padang, Kabupaten Tanggamus. Kantor kelurahan Desa Banjarsari terlatak di tengah lingkungan masyarakat yang dapat dikategorikan sebagai lingkungan yang padat penduduk. Para perangkat desa yang terdiri dari atas aparat desa, pengurus PKK dan Posyandu, serta pengurus Karang Taruna berkantor di sini. Desa ini termasuk ke dalam wilayah administratif Kecamatan Talang Padang, Kabupaten Tanggamus, yang memiliki luas wilayah $\pm 150 \mathrm{Ha}$, dengan jumlah penduduk pada tahun 2019 berjumlah 425 kepala keluarga (KK) yang terdiri dari \pm 1811 jiwa. Desa Banjarsari terdiri dari 4 rukun warga (RW) dan 2 rukun tetangga (RT), dibagi menjadi 4 dusun yaitu Dusun 1, Dusun 2, Dusun 3, Dusun 4.

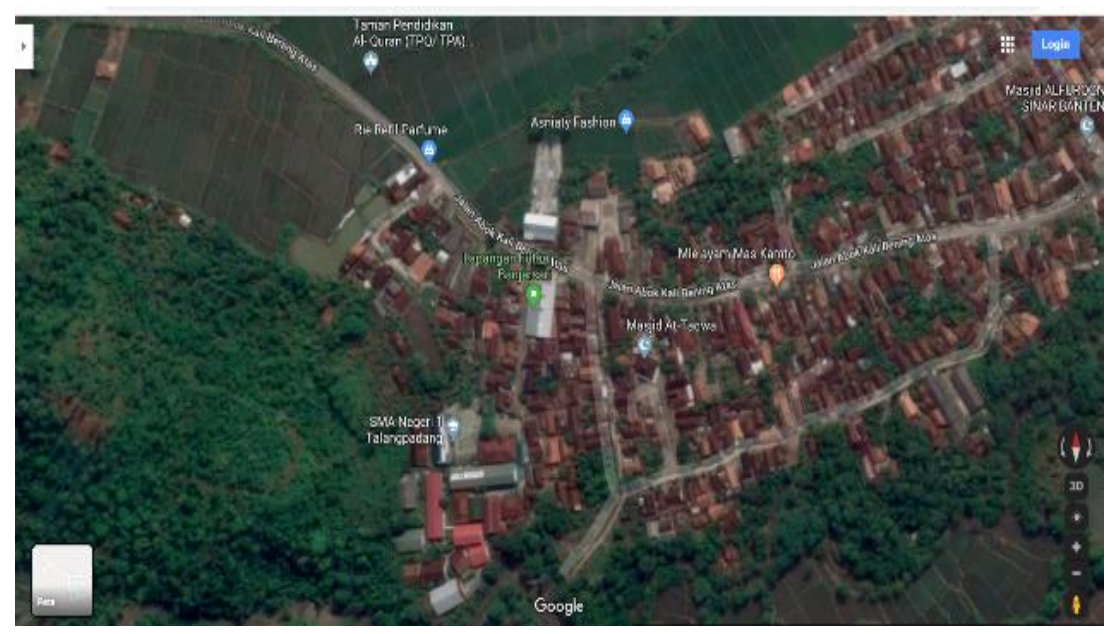

Gambar 1. Peta Desa Banjarsari Kecamatan Talang Padang, Kabupaten Tanggamus

Di Desa Banjarsari terdapat produksi susu kedelai yang dimiliki oleh Bapak Dul Alm. yang kini diwariskan kepada anaknya yang bernama Bapak Doi yang terletak di Dusun 1. Produksi ini sudah berjalan hingga 20 tahun lamanya. Pak Doi mampu memproduksi $3 \mathrm{~kg}$, dengan kapasitas 200 bungkus per hari dengan sistem produksi secara manual mulai dari proses penggilingan sampai pengemasan. Proses pemasaran dengan cara berkeliling dari kampung ke kampung. Setelah berjalannya waktu ia kini memiliki karyawan sebanyak 8 orang, dengan pembagian 5 orang di bagian pemasaran, dan 3 orang di bagian produksi.

Proses pembuatan susu kedelai menghasilkan limbah padat berupa ampas kedelai yang jarang dikonsumsi oleh manusia sehingga memiliki nilai ekonomis yang rendah. Seiring dengan meningkatnya jumlah susu kedelai yang diproduksi, maka jumlah ampas susu kedelai yang diperoleh juga semakin banyak. Ampas susu kedelai biasanya hanya dimanfaatkan oleh bapak Doi sebagai pakan ternak, padahal ampas atau yang bisa disebut okara itu masih memiliki nilai gizi yang tinggi seperti kandungan protein, lemak, serat pangan, mineral, monosakarida dan oligosakarida. Okara mentah memiliki kandungan isoflavone sebesar 22\%, sumber antioksidan yang potensial, bersifat prebiotik, menurunkan kadar kolesterol dan gula darah.

Penelitian sebelumnya telah banyak dilakukan yaitu tentang pemanfaatan kacang kedelai sebagai substitusi bahan baku tempe dan tahu (Haliza, Purwani, and Thahir 2016), sebagai bahan baku sumber protein untuk pangan darurat (Ekafitri and Isworo 2014), sebagai bahan pembuatan keju nabati (Fitriana 2015), tetapi belum pernah dilakukan kajian tentang pemanfaatan ampas susu kedelai menjadi nugget, sehingga hal tersebut menjadikan kebaruan dari penelitian ini. 
Berdasarkan uraian di atas, maka peneliti menggandeng ibu-ibu PKK desa banjarsari kecamatan Talang Padang, kabupaten Tanggamus untuk membuat inovasi baru dalam mengolah ampas susu kedelai menjadi produk yang bernilai jual lebih tinggi. Kegiatan pengabdian masyarakat yang dilakukan dimaksudkan untuk memberikan pengetahuan kepada Ibu-ibu PKK mengenai pengolahan ampas susu kedelai menjadi produk nugget.

\section{METODE}

Kegiatan ini dilaksanakan melalui beberapa metode, yaitu pendekatan, praktek penyuluhan, bimbingan teknis, dan pendampingan. Pendekatan yang dilakukan diawal kegiatan untuk mengetahui kapasitas produksi, proses pengolahan susu kedelai, serta kapasitas dan karakteristik ampas susu kedelai yang dihasilkan setiap kali produksi. Kegiatan selanjutnya yaitu praktek pengolahan ampas susu kedelai menjadi nugget. Kegiatan dilanjutkan dengan penyuluhan dan bimbingan teknis mengenai bagaimana pengolahan ampas susu kedelai menjadi nugget dengan ibi-ibu PKK. Kegiatan terakhir yaitu pendampingan untuk mengevaluasi dan memonitor pengolahan ampas susu kedelai menjadi produk olahan yang dilakukan oleh ibu-ibu PKK.

\section{HASIL DAN PEMBAHASAN}

Pelaksanaan program pengabdian ini didasarkan pada observasi awal yang mengindikasikan bahwa tingkat kreatifitas masyarakat terhadap peningkatan hasil usaha masih terbilang rendah dimana belum adanya pemanfaatan ampas susu kedelai. Keadaan tersebut kemudian mendorong adanya tindak lanjut berupa program berupa penyuluhan "pemanfaatan ampas susu kedelai menjadi nugget". Program ini dilaksanakan tanggal 28 Agustus 2019, yang bertempat di desa Banjarsari Kecamatan Talang Padang Kabupaten Tanggamus. Dengan berbagai program yang mendukung pemanfaatan ampas susu kedelai tersebut, sebagai upaya peningkatan ekonomi masyarakat di antaranya bimbingan pengolahan ampas susu kedelai menjadi nugget yaitu bahan layak konsumsi, pendampingan dan pelatihan keterampilan membuat varian produk ampas susu kedelai. Seluruh program yang dijalankan kemudian akan diobservasi dan diambil data dari berbagai sumber guna melakukan evaluasi. Dalam pengumpulan data hanya jenis data primer yang dikumpulkan, dimana data primer ini adalah data yang diperoleh secara langsung dari informan di lapangan termasuk rekomendasi dari pengurus Ibu-ibu PKK maupun perangkat desa setempat. Hasil pengumpulan data tersebut kemudian dianalisis dan dibuat kesimpulan apakah program layak untuk ditindaklanjuti atau tidak.

Pelaksanaan program pengabdian ini dilakukan dengan beberapa tahap, yaitu:

1. Pendekatan

Pendekatan dilakukan diawal kegiatan untuk mengetahui kapasitas produksi, proses pengolahan susu kedelai, serta kapasitas dan karakteristik ampas kedelai yang dihasilkan setiap kali produksi. Sehari bapak Doi mampu memproduksi 3 kg dengan kapasitas 200 bungkus susu kedelai. Proses pengolahan susu kedelai yaitu pertama timbang kedelai sesuai takaran yang ingin dibuat, kedua cuci bersih kedelai menggunakan air mengalir, ketiga rendam kedelai dengan air selama 8 jam cuci kembali dengan kulitnya. Keempat giling kedelai, lalu saring kedelai dengan kain untuk mendapatkan sari-sari kedelai atau pengepresan seperti gambar 1 . Kelima rebus hasil saringan kedelai dengan takaran 1:1 dimana air:gula. Perebusan ini membutuhkan waktu 1 jam. Jika ingin farian rasa bisa tambahkan jahe, atau pandan. Terakhir bungkus kedelai dengan plastik seperempat dan ikat dengan karet seperti gambar 2. Susu kedelai ini tidak bertahan lama maksimal 2 hari jika disimpan dilemari es. 


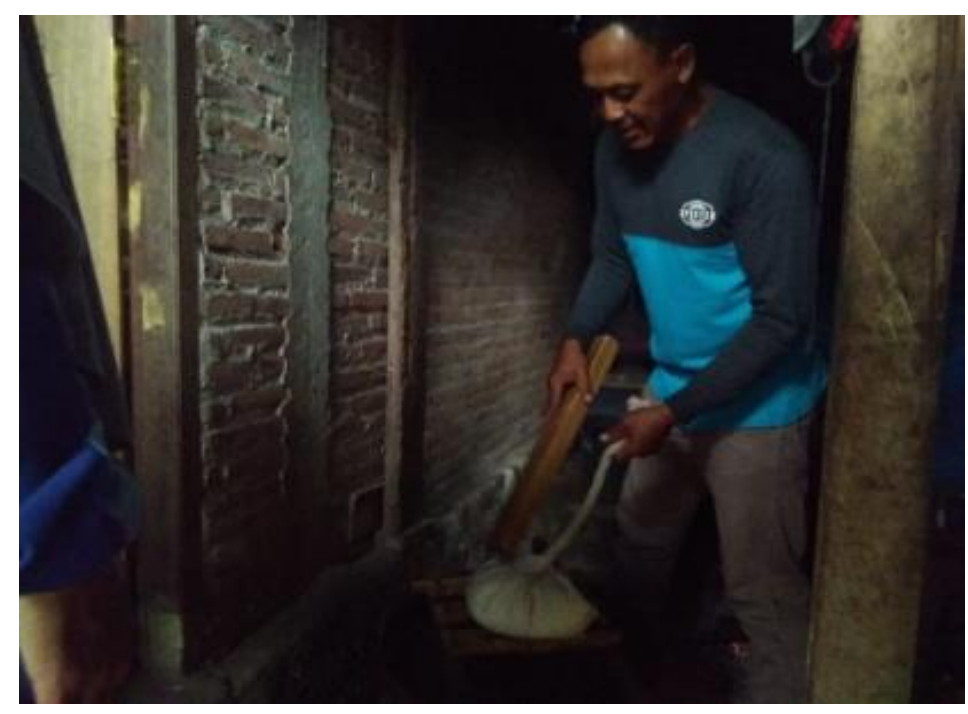

Gambar 2. Penyaringan atau Pengepresan Susu Kedelai

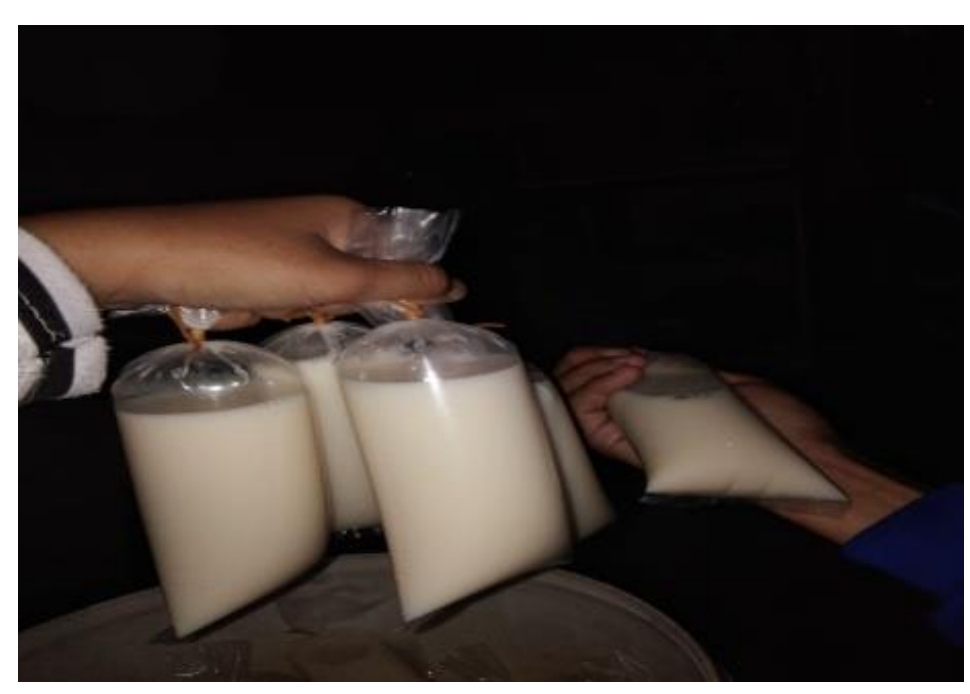

Gambar 3. Pembungkusan Susu Kedelai

2. Praktek

Berdasarkan pengolahan susu kedelai yang telah dilakukan, diperoleh ampas susu kedelai yang akan dimanfaatkan menjadi nugget berikut pembuatannya:

a. Bahan-bahan yang diperlukan yaitu:

$>$ Ampas susu kedelai $1 \mathrm{~kg}$ (Gambar 4)

$>$ Ayam giling $1 / 2 \mathrm{~kg}$

$>$ Terigu $1 / 4 \mathrm{~kg}$

$>$ Telur 5

$>$ Bawang putih 7 siung

$>$ Ketumbar setengah sedok makan

$>$ Lada setengah sedok makan

$>$ Garam setengah sedok makan

$>$ Aci/sagu 2 sendok makan 
$>$ Daun bawang 5 helai

$>$ Minyak setengah $\mathrm{kg}$

$>$ Tepung panir $1 / 4 \mathrm{~kg}$

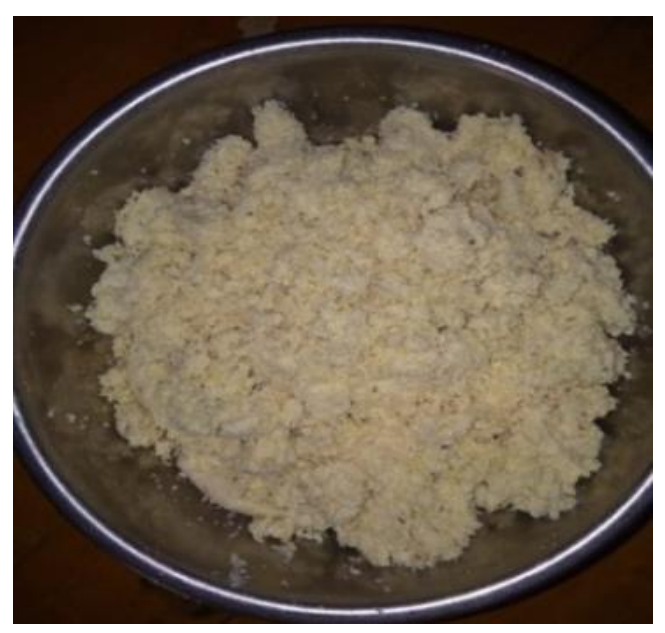

Gambar 4. Ampas Susu Kedelai

b. Alat-alat yang diperlukan antara lain:

$>$ Timbangan

$>$ Baskom

$>$ Loyang

$>$ Dandang

$>$ Wajan

$>$ Blender

$>$ Peniris

$>$ Spatula

$>$ Piring

$>$ Sendok.

c. Cara pembuatan:

Proses pembuatan nugget dari ampas susu kedelai diawali dengan menghaluskan bawang putih, tumbar, lada dan garam. Potong kecil-kecil daun bawang, setelah itu campur semua bahan-bahan kedalam baskom seperti ampas susu kedelai, ayam giling, bumbu yang sudah dihaluskan, aci/sagu 2 sendok, daun bawang dan terigu, selanjutnya uleni atau aduk agar tercampur rata. Kemudian pindahkan keloyang adonan tersebut untuk dikukus selam 30 menit. Setelah matang pindahkan nugget ke nampan lalu potong-potong atau bentuk sesuai selera. Langkah selanjutnya yaitu penggorengan sebelum di goreng maka celupkan nugget dengan telur kemudian balur dengan tepung panir hingga merata, lalu goreng nugget hingga warna kecoklatan.

3. Penyuluhan dan Bimbingan Teknis

Penyuluhan dan bimbingan teknis dilaksanakan di PAUD Kober Amanah Jejama Desa Banjarsari Kecamatan Talang Padang Kabupaten Tanggamus, tanggal 28 Agustus 2019 
bersama ibu-ibu PKK dengan penyuluhan "Pemanfaatan Ampas Kedelai Menjadi Nugget Sebagai Upaya Peningkatan Ekonomi Masyarakat Melalui Ibu-Ibu PKK Desa Banjarsari” ini dapat bermanfaat bagi masyarakat Banjarsari tertutama ibu-ibu PKK dimana diharapkan dengan adanya penyuluhan ini ibu-ibu dapat mencoba dan berinovasi dalam membuat suatu produk yang berguna dengan memanfaatkan bahan-bahan yang masih layak pakai seperti halnya ampas susu kedelai ini yang dapat kita manfaatkan menjadi nugget. Selain ampas susu kedelai yang digunakan ampas tahu juga dapat digunakan sebagai bahan utama, produk yang dibuat juga bisa beraneka ragam seperti brownies, biskuit, bola-bola dll.

Proses pengolahan produk nugget tidak ditemukan kesulitan yang cukup berarti. Ibuibu PKK diharapkan dapat mempraktekan proses pengolahan ampas susu kedelai menjadi produk nugget dimana dinilai cukup banyak digemari berbagai kalangan terutama baik digunakan untuk anak-anak yang dapat dikonsumsi dengan cara penambahan bahan-bahan lain berupa sayur-sayuran. Cara ini sangat bermanfaat bagi anak-anak yang tidak suka sayuran maka dapat di inovasi dengan membuat nugget yang bahan-bahannya sangat bergiziz, seperti dapat ditambahkan sayur-sayuran, Sehingga gizi anak dapat terpenuhi. selain itu tidak menggunakan bahan-bahan kimia. Adapun gambar nugget ampas susu kedelai tercantum dalam Gambar 4.

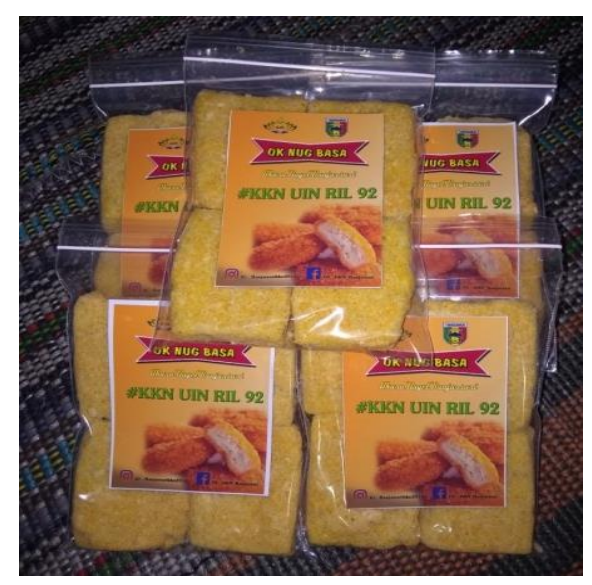

Gambar 5. Nugget Ampas Susu Kedelai

Gizi yang terkandung dalam ampas susu kedelai masih cukup tinggi, terutama protein dan serat hasil penelitian Sulistiani (2004) menunjukan bahwa ampas tahu mengandung air $89,9 \%$, protein $1,3 \%$, lemak $2,2 \%$, abu $0,3 \%$, karbohidrat $6,3 \%$, serat pangan tidak larut $1,0 \%$ dan serat larut 4,7\%. Yulianis (2004) menyatakan bahwa 100 gram tepung ampas tahu mampu memenuhi kebutuhan serat pangan (dietary fiber) sebesar 190,9\% dengan angka kecukupan serat pangan rata-rata 25 g/orang/hari (Gustiawan, Herawati, and Ayu 2018; Yustina 2011; Hardoko et al. 2018). Selama ini pengolahan ampas susu kedelai menjadi bahan pangan masih terbatas. Pengolahan ampas susu kedelai yang sudah pernah ada antara lain tempe gembus dan perkedel. Sebagian besar ampas kedelai digunakan untuk campuran pakan ternak. Ampas kedelai mudah rusak/ busuk, terutama setelah disimpan lebih dari 12 jam, karena masih mengandung air dan zat gizi yang tinggi, terutama protein (Septifani 2018; Yustina 2011).

Ampas susu kedelai yang merupakan hasil dari penyaringan industri susu kedelai maupun tahu memiliki kelemahan sebagai bahan pakan yaitu kandungan serat kasar dan air yang tinggi (Harahap, Wijaya, and Widowati 2017). Alternatif pemanfaatan tahu untuk dijadikan tepung dalam pembuatan biskuit akan lebih menguntungkan, karena lebih ekonomis dan membantu pengusaha dalam penanganana limbahnya mewujudkan industri ramah lingkungan. Selain itu protein dan lemak yang masih tersisah dalam ampas tahu 
diharapkan dapat meningkatkan kandungan protein dan lemak biskuit (Suhartini and Hidayat 2005; Sulistiyaningrum 2017).

Pada saat penyuluhan berlangsung pemateri yaitu dari mahasiswa KKN menyampaikan bahwa terdapat manfaat pada tubuh kita jika mengkonsumsi kedelai, yaitu dapat mencegah penyakit kardiovaskuler atau dikenal juga dengan penyakit jantung terjadi karena penyumbatan pada pembuluh darah. Zat yang terkandung pada ampas susu kedelai seperti antioksidan, serat, dan mineral dapat mencegah terjadinya penyumbatan darah yang memicu penyakit jantung dan stroke. Menjaga sistem pencernaan diamana pada ampas kedelai terkandung zat fiber atau serat yang membantu dalam penyerapan makanan oleh tubuh. Menjaga kesehatan kulit isoflavon yang berada pada ampas kedelai sangat bermanfaat untuk kesehatan kulit, utamanya adalah untuk menjaga elastisitas kulit sehingga kulit tampak lebih muda. Mencegah osteoporosis, osteoporisis adalah penyakit lainnya yang terkait dengan usia dan hormon. Fitoestrogen pada kedelai dapat membantu mempercepat penyerapan kalsium oleh tubuh dan mencegah hilangnya massa tulang. Mencegah Kanker Prostat kedelai merupakan sumber yang baik dari fitoestrogen, yaitu hormon tanaman yang dapat menghambat produksi testosteron pada pria. Dengan mengurangi kadar testosteron secara signifikan dapat membantu dalam mengurangi risiko kanker prostat. Dengan mengetahuinya manfaat-manfaat tersebut diharapkan ibu-ibu PKK dapat mengkonsumsi kedelai dengan berbagai olahan seperti tahu, susu kedelai, nugget ampas susu kedelai dan olahan lainya. Yang jelas sekali bahwa manfaat dari kedelai sangat banyak serta gizi yang terkandung juga sangat banyak jika dikonsumsi setiap hari.

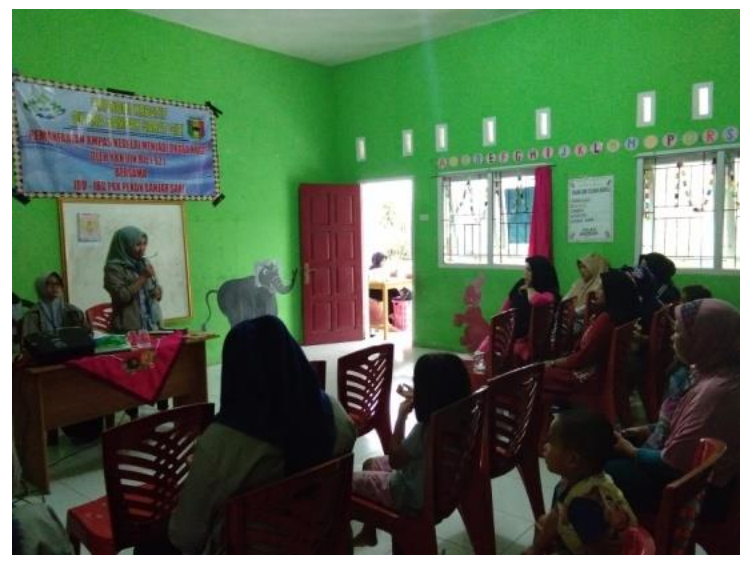

Gambar 6. Pelaksanaan Kegiatan

Setelah materi selesai diberikan, dibuka sesi tanya jawab sekaligus memperkenalkan produk nugget. Kegiatan ini dapat diketahui bahwa antusias peserta untuk memperoleh keterampilan dan kemampuan tentang pemanfaatan limbah susu kedelai sebagai bahan utama pembuatan nugget. Begitu pula ibu-ibu PKK sangat antusias mengikuti penyuluhan tersebut, dimana banyak yang melontarkan pertanyaan-pertanyaan terkait proses pembuatan nugget. Rangsangan untuk meningkatkan produk direspon dengan baik oleh peserta, sehingga memberikan harapan bagi upaya perbaikan kualitas konsumsi pangan hewani dan membuka peluang kepada ibu-ibu PKK untuk melakukan kegiatan lanjutan yang bersifat kontinuitas dan berkesinambungan sehingga ibu-ibu PKK dapat terbina.

4. Pendampingan 
Pendampingan ibu-ibu PKK, harapan ibu-ibu PKK saat penyuluhan berlangsung salah satu ide ini dapat berlanjut dimana produk ini yaitu nugget dengan pemanfaatan ampas susu kedelai ini dapat berjalan, bersama ibu-ibu PKK, dan dapat bekerjasama dengaan Badan Usaha Milik Desa (BUMDES) yang merupakan salah satu program strategis dalam upaya meningkatkan kesejahteraan ekonomi masyarakat yang ada di desa Banjarsari. Harapan ini disampaikan oleh Kertua PKK yaitu Ibu Dina, agar para anggota dapat memiliki kesadaran, semangat untuk membangun PKK dengan cara berinovasi, berkreasi, dan aktif dalam kegiatan-kegiatan PKK. Produk ini dinamakan "OK NUG BASA" yang memiliki arti Okara (ampas susu kedelai) Nugget Banjarsari, nama tersebut dapat digunakan sebagai lebel dari nugget banjarsari dalam peroses pemasaran nantinya, menurut mahasiswa KKN.

\section{Rencana Keberlanjutan Program}

Harapan kedepannya dengan dilakukannya penyuluhan mengenai pemanfaatan ampas susu kedelai menjadi nuuget dapat meningkatkan ekonomi masyarakat banjarsari, tidak lagi kebingungan untuk memanfaatkan ampas susu kedelai yang menghsilkan nilai jual dan bergizi. Diharapkan program ini tetap dilaksanakan oleh Ibu-ibu PKK walaupun kegiatan penyuluhan dan pengawasan telah selesai. Dengan dilaksanakannya program ini, adannya peningkatan ekonomi dimasyarakat dan keaktifan Ibu-ibu PKK. Pelaksanaan program penyuluhan pembuatan Nugget memiliki harapan jangka panjang yaitu masyarakat dapat membuat produk makanan yang sehat dan aman tanpa bahan pengawet atau bahkan bahan kimia bagi keluarganya. masyarakat dapat membuat home industry pembuatan nugget untuk memperoleh pendapatan tambahan agar dapat meningkatkan perekonomian keluarga.

\section{KESIMPULAN}

Limbah dari susu kedelai yang berupa ampas susu kedelai dapat dimanfaatkan sebagai produk olahan seperti nugget yang kaya akan gizi, dan adanya nilai jual yang biasanya hanya dibuang atau sebagai pakan ternak secara cuma-cuma kini dapat meningkatkan ekonomi masyarakat banjarsari dengan cara kerjasama antara ibu-ibu PKK dan BUMDES. Untuk membuat "OK NUG BASA". Penyuluhan pembuatan nugget mendapatkan respon positif dari warga desa Banjarsari Kecamatan Talang Padang Kabupaten Tanggamus. Hal ini terlihat dari tingkat keikutsertaan dan keaktifan warga pada saat penyuluhan. Melalui penyuluhan ini diharapkan warga desa dan Banjarsari memiliki keterampilan dalam mengelola sumber daya alam dan sumber daya manusia yang ada agar dapat meningkatkan tingkat perekonomian warga desa.

\section{UCAPAN TERIMA KASIH}

Penulis mengucapkan terima kasih kepada ibu-ibu PKK dan BUMDES Desa Banjarsari Kecamatan Talang Padang, Kabupaten Tanggamus yang telah bersedia menjadi lokasi pengabdian ini.

\section{DAFTAR PUSTAKA}

Ariani, Mewa. 2015. 'Dinamika Konsumsi Beras, Jagung Dan Kedelai Mendukung Swasembada Pangan'. Badan Penelitian Dan Pengembangan Pertanian.

Ekafitri, Riyanti, and Rhestu Isworo. 2014. 'Pemanfaatan Kacang-Kacangan Sebagai Bahan Baku Sumber Protein Untuk Pangan Darurat The Utilization of Beans as Protein Source for Emergency Food'. Jurnal Pangan 23 (2): 134-45.

Ernawati, Ernawati. 2013. 'Uji Bakteriologis Sari Kedelai Buatan Industri Rumah Tangga Yang Dijual Di Pasar Tradisional Kabupaten Sukoharjo'. Universitas Setia Budi Surakarta.

Fitriana, Zahrotul Wahidah. 2015. 'Pemanfaatan Kacang Tunggak (Vigna Unguiculata L. Walp) Sebagai Bahan Pembuatan Keju Nabati Berkalsium Tinggi’. UIN Walisongo. 
Gustiawan, Sandy, Netti Herawati, and Dewi Fortuna Ayu. 2018. 'Pemanfaatan Tepung Biji Nangka Dan Tepung Ampas Tahu Dalam Pembuatan Mi Basah'. Jurnal Sagu 17 (1).

Haliza, Winda, Endang Yuli Purwani, and Ridwan Thahir. 2016. 'Pemanfaatan Kacang-Kacangan Lokal Sebagai Substitusi Bahan Baku Tempe Dan Tahu'. Buletin Teknologi Pasca Panen 3 (1): $1-8$.

Harahap, Yunita, Agus Wijaya, and Tri Wardani Widowati. 2017. 'Pengaruh Penambahan Sari Buah Mangga Dan Susu Skim Terhadap Karakteristik Yogurt Kedelai'. Sriwijaya University.

Hardoko, Hardoko, Bambang Budi Sasmito, Yunita Eka Puspitasari, and Nyimas Lilyani. 2018. 'Konversi Ikan Asin Menjadi Nugget Berserat Pangan Dengan Mencampurkan Ampas Tahu Dan Beberapa Jenis Binder'. Jurnal Pengolahan Hasil Perikanan Indonesia 21 (1): 54-67.

Pamuji, Wahyu Hari. 2018. 'Pengaruh Pupuk Kascing Dan Inokulum Rhizobium Terhadap Pertumbuhan Dan Hasil Kedelai'. Universitas Mercu Buana Yogyakarta.

Panataria, Lince R. 2015. 'Pengaruh Kemasan Simpan Terhadap Viabilitas Benih Kedelai (Glycine Max (L.) Merrill)'. MAJALAH ILMIAH METHODA 5 (1): 72-77.

Rohmani, Sholichah, Adi Yugatama, and Fea Prihapsara. 2018. 'Inovasi Minuman Sehat Berbahan Kedelai Dalam Upaya Pemberdayaan Masyarakat Melalui Wirausaha Di Kabupaten Sukoharjo'. Agro Kreatif Jurnal Ilmiah Pengabdian Kepada Masyarakat 4 (2): 68-74.

Septifani, Riska. 2018. 'Pemanfaatan Ampas Kedelai Sebagai Produk Pangan Dengan Nilai Tambah Ekonomis Di Ukm Susu Kedelai. Kota Batu'. Journal of Innovation and Applied Technology 4 (2): 784-88.

Suhartini, Sri, and Nur Hidayat. 2005. 'Olahan Ikan Segar'. Trubus Agrisarana. Surabaya.

Sulistiyaningrum, Feny. 2017. 'Optimasi Penggunaan Ampas Tahu, Mocaf Kulit Limbah Singkong Dan Ganyong (Canna Edulis Kerr) Pada Pembuatan Tepung Komposit Yang Diperuntukan Untuk Cookies Menggunakan Program Linier'. Fakultas Teknik.

Susilawati, Susilawati. 2018. 'Penyuluhan Dan Pelatihan Pembuatan Kefir Susu Kambing Dalam Rangka Meningkatkan Gizi Masyarakat Di Desa Sumber Rejo Kecamatan Jati Agung Kabupaten Lampung Selatan'. Sakai Sambayan Jurnal Pengabdian Kepada Masyarakat 1 (3): 140-44.

Wiyarsi, Antuni. 2005. 'Teknik Pembuatan Dan Pengawetan Susu Kedelai'.

Yustina, Ita. 2011. 'Pemanfaatan Ampas Pen Golahan Kedelai Dalam Pembuatan Rengginang'. In Prosiding Seminar Hasil Penelitian Tanaman Aneka Kacang Dan Umbi.

Zaini, Ziana Octa Faridah. 2016. 'Pengaruh Lama Fermentasi Terhadap Nilai PH, Total Asam, Jumlah Mikroba, Protein, Dan Kadar Alkohol Kefir Susu Kacang Kedelai (Glycine Max (l) Merill)'. Universitas Islam Negeri Maulana Malik Ibrahim. 